various times, other Latin American nations such as Venezuela and Argentina have sought to build up science and technology by supporting a mixture of pure and applied research, a model similar to that established in wealthier countries. Cuba took a different approach: research there is ruthlessly applied.

Cuba's state-sponsored science is structured like a corporate research laboratory, except that its output consists of social outcomes, rather than commercial products. If a project looks likely to earn foreign currency or meet the government's social objectives, it is but they largely back their government's approach, in part because they have seen how it transformed health services in their country.

But the approach has many drawbacks. One concerns the constraints that it places on the movement of researchers. Castro's govScientists fare better than most, and are frequently allowed to attend conferences or spend time working in foreign laboratories. Yet if they stay away for longer than permitted, they lose the right to return freely. This draconian approach to dealing with the threat of a brain drain is in breach of the Universal Declaration of Human Rights, adopted by the United Nations in 1948. Restrictions on free political expression in Cuba are also inconsistent with the declaration.

It is questionable, in any case, whether such restrictions serve any useful purpose for Cuba's government, given the obvious commitbacked to the hilt. Cuba's scientists have no funds for basic research, ernment maintains strict control on the movement of its citizens.

ment of the scientists in question to their country's future. Just as questionable is the purpose served by the continuing US trade embargo on Cuba, which continues to isolate scientists and others on the island from their colleagues in the United States, including a large group of Cuban origin.

The embargo damages Cuban science and scientific collaboration in various ways. A Cuban proposal for dengue research, for example, won a $\$ 700,000$ award from the Bill \& Melinda Gates Foundation after international peer review. But the award has been held up for a year, lest the illustrious Microsoft founder,
"Cuba's science is structured like a corporate research lab, except that its output consists of social outcomes not commercial products." his wife and their fellow trustees be dragged off to the penitentiary for breaching the embargo.

Nature has consistently opposed scientific embargos, and strongly believes in research collaboration as a means of building bridges between nations that lack normal diplomatic relations. But there is a more specific issue here. When Castro dies, Cuba faces a period of volatility that could endanger key national assets, such as its science. In preparation for that day, both Havana and Washington should be acting now to wind down such cold-war artefacts as Cuba's travel restrictions and the US trade embargo.

\section{Agency under siege}

\section{Conflicts-of-interest at the US National Institutes of Health justify the agency's ethics crackdown.}

7 he latest information to emerge from an investigation by Congress into potentially unethical links between outside companies and researchers at the US National Institutes of Health (NIH) isn't particularly encouraging.

At the request of Congress, the biomedical research agency has been looking into the activities of 81 researchers whose names appeared on lists of consultants provided by biotechnology and pharmaceutical companies, but who hadn't declared their interest to the NIH.

Earlier this month, the NIH's director, Elias Zerhouni, told Joe Barton (Republican, Texas), chair of the House Committee on Energy and Commerce, that about half of the 81 were found to be in breach of the ethics rules that were in force at the time of their consultancy work. Most of the infractions were minor, but eight have been referred to the health department's inspector-general for further investigation.

The steady drip of this sort of information into the public domain since December 2003, when the Los Angeles Times first reported a few egregious examples of conflict-of-interest at the $\mathrm{NIH}$, is taking its toll on the public reputations of the agency and its staff.

Zerhouni has moved swiftly to confront the issue. His clampdown on consultancy arrangements and on the holding of investments among thousands of NIH employees has caused much wailing and gnashing of teeth at the agency's main campus in Bethesda, Maryland.
But the rules are being implemented with extended deadlines to allow people sufficient time to alter their financial arrangements.

The clampdown leaves the NIH's intramural staff in a bind, unable to collaborate closely with the biotechnology industry at a time when such interactions have become almost routine for researchers in some sub-disciplines. At some stage, collaboration between researchers and industry must be redeveloped on a basis that will be consistent with the public's reasonable expectations of publicly funded researchers.

Details of the latest batch of infractions haven't been released, but many of them are probably minor, such as meeting an off-site collaborator without requesting a half-day's vacation. Congress is angry because the interactions weren't properly reported under the NIH's previous ethics regime. In some cases, that happened not out of any nefarious intent, but because the NIH is a large and diffuse federation of centres and institutes.

Now Barton's committee wants to centralize the agency. A draft reauthorization bill for the agency would give far more authority to the director's office, and support additional and extensive monitoring and reporting functions there, as well as giving the director more power to enforce cooperation between institutes and centres.

Some reform is due, but this measure goes too far. The NIH needs to modernize, but shouldn't overthrow the autonomy of centres and institutes that has served it so well in the past.

The eventual solution should involve a mixture of self-awareness and common sense. Researchers need to recognize that the conflictof-interest issue can no longer be brushed off as something for politicians and the press to worry about. The cases that have already been exposed at the NIH amply demonstrate how germane the matter is to biomedical research. 